\section{$\$$ Research Square}

\title{
Coping strategies adopted by post graduate trainee in dealing with work related stress: (A mixed method study)
}

\author{
University of health Sciences, Lahore \\ Madiha Sajjad \\ RIPHAH International University \\ Idrees Anwar \\ Rawalpindi Medical University

\section{Aisha Rafi} \\ Shifa Tameer-e-Millat University
}

Shamaila Manzoor ( $\sim$ Shamaila1.Manzoor@gmail.com )

\section{Research Article}

Keywords: Coping strategy, Fatigue, Post-graduate trainee, long working hours

Posted Date: October 12th, 2021

DOI: https://doi.org/10.21203/rs.3.rs-957293/v1

License: (c) (1) This work is licensed under a Creative Commons Attribution 4.0 International License. Read Full License 


\section{Abstract}

Back Ground: During residency period, doctors all around the globe, experiences stressful working environment and prolonged working hours. These factors leads to lack of concentration, distress and higher level of fatigue; however, residents counter the effects of these extensive, high demanding duty hours by various coping strategies. Although the effects of extended duty hours and various coping strategies used by the doctors have been studied at large. Yet, the difference between the effects \& coping styles of trainees of various high demanding specialties' have not been studied. Therefore, this study was carried out to identify and explore the difference in coping strategies for dealing with stress, adopted by post graduate trainees in surgical and non-surgical specialties.

Methods: Mixed method approach, with explanatory sequential design was opted for this study. In phase one (quantitative) data was collected by a web based survey; carried out in five teaching hospitals of Rawalpindi \& Muzaffarabad in 2020. Data was analysed on SPSS, frequencies and major trends were recorded. An open ended questionnaire was developed on the basis of phase 1 results. In phase two (qualitative), six focus group discussions were carried out with 24 participants to explore the various coping strategies adopted in different situations among the post graduate trainees working in different specialties. Later on, verbatim transcription was done \& data analysed manually.

Results: Out of 250 (100\%) possible participants, 146 (58\%) participant responded on-line survey. Where, residents of surgical discipline has a higher response rate $(60 \%, n=87)$ than non-surgical. Moreover, female participation $(54 \%, n=79)$ was greater than males $(46 \%, n=67)$. Mann-Whitney $U$ test was statistically significant only for seeking medical advice to cope with stress $(P=.029)$.

In focus group discussions, female involvement was more $(58 \% \mathrm{n}=14)$ as compare to males $(42 \% \mathrm{n}=10)$. Following themes were developed after data analysis, that is; self-regulation, tailor made strategies, educational focus and support system.

Conclusion: Quantitatively, no significant difference was found between the coping strategies of post graduate trainees of surgical \& non-surgical trainee, against work related stress. However, minor differences were obtained qualitatively.

\section{Introduction:}

Resident training is an arduous period marked with psychological and intellectual changes in resident doctors, while healing the ailing humanity. The prolonged duty hours in training are exhaustive leading to weariness of doctors(1). It causes sleepiness which leads to slowing of sensorimotor and cognitive functions in trainee doctors, becoming a safety hazard for both patient and doctor(2). The exhaustive duty has been strongly associated with fatigue, sleep deprivation and workplace difficulties. Such factors leads to diminished critical thinking and decision making instigating more medical errors at this professional stage(3)(4).

Literature review has revealed that physicians use various coping mechanism like acceptance, mindfulness, spirituality, socializing, provocative and leisure activities mainly based on the Lazarus coping theory(5)(6). Frequently, emotion and problem focused coping strategies found to be the established habits of doctors. They sacrifice their personal desires over professional demands. However, when there is an imbalance between job demands and one's capacity to cope, the situation becomes traumatic(7). Their self-esteem suffers, so, they react by exhibiting anger towards the patients and bitterness to the superiors, with further harm to themselves and to their patients(8). Commonly, these individuals are more prone to high emotional exhaustion and depersonalization(9)(10). Whereas, adapting customized coping mechanisms like binging/ eating at night shifts helps to stay alert \& awake(11). Similarly, taking interval from job, leisure activities, switching off intellectually and emotionally from work during off job time, has positive benefit for workers(12). This strategy is more prevalent in conscientious personalities, mainly female physicians. Subsequently, post-graduate trainees uses various coping strategies, to reduce their emotional and physical stress created by their high acuity jobs. Unfortunately, no formal teaching or training has been provided to overcome such job related issues and no formal curricular plans are in place to cope with these prolonged duty related challenges(13)(14). 
Therefore, this study was conducted to identify and explore the difference between various coping mechanisms used by postgraduate trainees. This would help in reviewing and revising the training programs regarding working hours and job-related stress which in turn would result in better patient care.

The quantitative phase (phase I) of study revolved around following enquiry. What are the effects of long duty hours and various coping mechanisms adopted by post graduate trainees (PGTs) of surgical and non-surgical specialties?

The qualitative part (phase II) of study was addressed by exploring and differentiating various coping strategies adopted by the residents of surgical \& non- surgical specialties to deal with stress resulting from long working hours?

\section{Material \& Methods:}

Mixed method study design was considered as best approach to answer our research question. As, it was feasible for both researchers \& target audience (medical educationist, teachers, policy makers, stake holders \& post graduate trainees) who were well versed with mixed method approach. A mixed method study, with an explanatory sequential approach, was carried out from March 2020 to Sep 2020(15). Study was conducted after institutional Review Committee (IRC) approval from RIPHAH International University, Islamabad (Appl\#Riphah/IRC/20/123). Subsequently, study was conducted in five major teaching hospitals of Rawalpindi and Muzaffarabad. Only those post graduate trainees (FCPS year 2, 3 \& 4 trainees) attending long hour calls in surgical and non-surgical specialties were included in study by purposive sampling(16).

Subsequently, explanatory sequential design was used. This design is comprised of two distinct phases where quantitative \& qualitative data is collected sequentially. First quantitative data is collected followed by qualitative one to explain the quantitative statistics.

Therefore, in phase 1, an online survey questionnaire was developed after thorough literature review. This questionnaire was developed by the researchers who are either medical educationist or having a sound knowledge and back ground of medical education. The questionnaire was vetted with pertinent experts and its piloting was done with small sample to check the feasibility of survey. Later, this questionnaire was circulated among the maximum number of participants $(n=250)$ more than the sample size calculated. This was keeping in view the possibility of the dropouts or failure to respond. Total 146 PGTs participated in this on-line survey. Therefore, response rate was $58 \%(n=146)$ out of 250 participants. Data was entered in SPSS version 22. Non-parametric Man Whitney-U test was applied on data to find the statistically significant difference in the coping strategies adopted by surgical and non-surgical post graduate trainees. Compilation, analysis and interpretation of quantitative data identified specific trends about the coping strategies of PGTs. Subsequently, in phase 2 (qualitative part) phenomenology approach helped to understand the effects of long working hours and counter measures used by PGTs, performing long duties. Therefore, six focus group discussion (FGDs) were conducted involving 24 post graduate trainees. These FGDs were based on open ended questionnaire developed after analysis of quantitative data by researchers.

Participants were from the same cohort as of quantitative study. In phase II, qualitative data collected, after these FGDs was transcribed verbatim. Data handling was done manually, open and axial codes were derived from data. Thematic analysis of qualitative data resulted in to sub-themes and themes formation. While, rigor of study was maintained by purposive sampling, good sample size, member checking and proficient data analysis.

\section{Results:}

Out of $100 \%(n=146)$ participants; $54 \%(n=79)$ were females, while $46 \%(n=67)$ were males. The average age of the participants were 27_+1 year. Surgical disciplines had a response rate of $60 \%(n=87)$ and non-surgical disciplines had $40 \%$ $(n=59)$. Among them eighty-two percent $(82 \%, n=120)$ participants work for more than 80 hours a week. The variables studied (effects of long working hours) were exhaustion $(46.6 \%, n=68)$, lost in environment $(41.4 \%, n=60)$, errors or negligence $(25 \%$, $n=36)$, disturbed relations with the family $(41.1 \%, n=60)$ effect on academic performance $(43.2 \%, n=62)$. 
Table 1

Statistical Analysis of effects of prolonged duties

\begin{tabular}{|c|c|c|c|c|c|c|c|c|}
\hline \multirow{3}{*}{$\begin{array}{l}\mathrm{Sr} \\
\text { no. }\end{array}$} & \multirow{3}{*}{$\begin{array}{l}\text { Survey questions about } \\
\text { effects }\end{array}$} & \multicolumn{2}{|l|}{ Frequency (n) } & \multirow{3}{*}{$\begin{array}{l}\text { Percentage } \\
(\%)\end{array}$} & \multirow[t]{3}{*}{ Median } & \multirow[t]{3}{*}{ Mode } & \multirow{3}{*}{$\begin{array}{l}\text { Mann- } \\
\text { Whitney } \\
\text { test }\end{array}$} & \multirow{3}{*}{$\begin{array}{l}\text { [p- } \\
\text { value] }\end{array}$} \\
\hline & & Rarely/ & Frequently/ & & & & & \\
\hline & & Occasionally & $\begin{array}{l}\text { Very } \\
\text { frequently }\end{array}$ & & & & & \\
\hline 1. & Feeling sleeping at work & & 72 & $50 \%$ & 3.00 & 3 & 2388.000 & .441 \\
\hline 2. & Slowing of reflexes & & 55 & 37 & 4.00 & 4 & 2512.000 & .962 \\
\hline 3. & $\begin{array}{l}\text { Tiredness at work( during } \\
\text { extended duties) }\end{array}$ & & 68 & $46 \%$ & 4.00 & 4 & 2415.000 & .641 \\
\hline 4. & Lost from surroundings & 60 & & $41.1 \%$ & 4.00 & 4 & 2206.000 & .177 \\
\hline 5. & $\begin{array}{l}\text { Chances of error at work } \\
\text { place }\end{array}$ & 71 & & $48 \%$ & 3.00 & 3 & 2393.500 & .573 \\
\hline 6. & $\begin{array}{l}\text { Detachment from } \\
\text { environment }\end{array}$ & 50 & & $34 \%$ & 3.00 & 3 & 2559.000 & .975 \\
\hline 7. & $\begin{array}{l}\text { Strained relation with } \\
\text { family }\end{array}$ & & 60 & $41 \%$ & 4.00 & 4 & 2478.500 & .712 \\
\hline 8. & Irregular/skipping meals & & 74 & $50 \%$ & 5.00 & 5 & 2222.000 & .131 \\
\hline 9. & $\begin{array}{l}\text { Effects on physical \& } \\
\text { mental health }\end{array}$ & 61 & & $41.7 \%$ & 3.00 & 3 & 2326.000 & .312 \\
\hline 10. & $\begin{array}{l}\text { Effect on educational } \\
\text { performance }\end{array}$ & & 63 & $43.1 \%$ & 4.00 & 4 & 2562.000 & .985 \\
\hline 11. & $\begin{array}{l}\text { Effect of educational } \\
\text { failure on performance at } \\
\text { work }\end{array}$ & & 83 & $56 \%$ & 3.00 & 3 & 2243.000 & .549 \\
\hline
\end{tabular}

The coping mechanism were taking caffeinated drinks $(52.7 \%, n=76)$, talking to their colleagues $(35.6 \%, n=51)$ and eating/munching $(41.1 \%, n=60)$. Nevertheless, majority of doctors neither smoked $(79 \%, n=115)$ nor used drugs/ alcohol as coping mechanism $(86 \% n=125)$, likewise, error at work place was occasional. 
Statistical analysis of web based survey about coping strategies

\begin{tabular}{|c|c|c|c|c|c|c|c|c|}
\hline \multirow{2}{*}{$\begin{array}{l}\mathrm{Sr} \\
\text {.no }\end{array}$} & \multirow{2}{*}{$\begin{array}{l}\text { Survey } \\
\text { Questions about } \\
\text { coping }\end{array}$} & \multicolumn{2}{|l|}{ Frequency (n) } & \multirow{2}{*}{$\begin{array}{l}\text { Percentage } \\
\text { (\%) }\end{array}$} & \multirow[t]{2}{*}{ Median } & \multirow[t]{2}{*}{ Mode } & \multirow{2}{*}{$\begin{array}{l}\text { Man- } \\
\text { Whitney } \\
\text { Test }\end{array}$} & \multirow{2}{*}{$\begin{array}{l}\text { [p- } \\
\text { value] }\end{array}$} \\
\hline & & Occasionally/Rarely & $\begin{array}{l}\text { Frequently/very } \\
\text { frequently }\end{array}$ & & & & & \\
\hline 1. & $\begin{array}{l}\text { Formal training/ } \\
\text { stress } \\
\text { management } \\
\text { workshop at } \\
\text { start of training }\end{array}$ & & 0 & $0 \%$ & 2.00 & 2 & 2524.000 & .626 \\
\hline 2. & $\begin{array}{l}\text { Frequency of } \\
\text { power naps to } \\
\text { remain alert }\end{array}$ & & 87 & $59.5 \%$ & 3.00 & 3 & 2536.000 & .895 \\
\hline 3. & $\begin{array}{l}\text { Frequency of } \\
\text { micro breaks to } \\
\text { remain fresh }\end{array}$ & & 92 & $63 \%$ & 3.00 & 3 & 2268.000 & .201 \\
\hline 4. & $\begin{array}{l}\text { Intake of } \\
\text { caffeinated } \\
\text { drinks }\end{array}$ & & 77 & $52 \%$ & 4.00 & 4 & 2333.500 & .311 \\
\hline 5. & $\begin{array}{l}\text { Help from } \\
\text { seniors/mentors } \\
\text { to cope with } \\
\text { long duties }\end{array}$ & & 114 & $78 \%$ & 3.00 & 3 & 2109.500 & .058 \\
\hline 6. & $\begin{array}{l}\text { Seeking social } \\
\text { support as } \\
\text { coping } \\
\text { mechanism }\end{array}$ & & 89 & $60 \%$ & 3.00 & 3 & 2372.000 & .420 \\
\hline 7. & $\begin{array}{l}\text { Talking to } \\
\text { friends and } \\
\text { family }\end{array}$ & & 79 & $54 \%$ & 3.00 & 3 & 2420.000 & .541 \\
\hline 8. & $\begin{array}{l}\text { Talking to } \\
\text { colleagues as } \\
\text { coping strategy }\end{array}$ & & 52 & $35 \%$ & 3.00 & 4 & 2349.000 & .461 \\
\hline 9. & $\begin{array}{l}\text { Food as mood } \\
\text { elevator }\end{array}$ & & 60 & $41 \%$ & 4.00 & 4 & 2481.000 & .723 \\
\hline 10. & $\begin{array}{l}\text { Seeking medical } \\
\text { advice }\end{array}$ & 47 & & $32 \%$ & 2.00 & 1 & 2044.000 & .029 \\
\hline 11. & $\begin{array}{l}\text { Drug/Alcohol } \\
\text { intake as coping } \\
\text { strategy }\end{array}$ & 126 & & $86.3 \%$ & 1.00 & 1 & 2500.000 & .657 \\
\hline 12. & $\begin{array}{l}\text { Smoking at } \\
\text { work place }\end{array}$ & 115 & & $78 \%$ & 1.00 & 1 & 2507.000 & .740 \\
\hline 13. & $\begin{array}{l}\text { Any incentive at } \\
\text { work }\end{array}$ & 130 & & $89 \%$ & 2.00 & 2 & 2481.000 & .357 \\
\hline
\end{tabular}

*5_very frequently, 4_f frequently, 3_ occasionally, 2_ rarely, $1 \_$Never

Then Mann-Whitney (MWU) was applied, resultant $P$-values were statistically non-significant $(P>0.05)$ in all cases, with one exception, that is, seeking medical advice to cope the deleterious effects of long duties $(P=.029)$. Hence, there was no statistically significant difference found between the coping strategies, employed by post graduate trainees. 
Total six FGDs were carried out, with twenty-four (24) PGTs. In these FGDs female response rate was higher $(\mathrm{n}=14,58 \%)$ as compare to males $(n=10,42 \%)$. After data analysis, four main themes were developed; self-regulation, tailor made strategies, educational focus and support system.

Table 3

Qualitative study Findings

\begin{tabular}{|c|c|c|c|}
\hline Themes & Sub- themes & Axial coding & Open coding \\
\hline \multirow[t]{3}{*}{$\begin{array}{l}\text { Self- } \\
\text { regulation }\end{array}$} & & $\begin{array}{l}\text { Time } \\
\text { management }\end{array}$ & Extended duties, compromised self- care and sleep \\
\hline & & Self-control & $\begin{array}{l}\text { Reflection on actions, controlling mood swings, Requesting } \\
\text { rotational duties }\end{array}$ \\
\hline & & $\begin{array}{l}\text { Countering } \\
\text { negative } \\
\text { emotions }\end{array}$ & $\begin{array}{l}\text { Regret in carrier selection (negative coping), self-counselling, } \\
\text { seeking senior help, fed-up from duty }\end{array}$ \\
\hline \multirow[t]{10}{*}{$\begin{array}{l}\text { Tailor made } \\
\text { strategies }\end{array}$} & \multirow[t]{3}{*}{ Dietary } & $\begin{array}{l}\text { Caffeinated } \\
\text { drinks }\end{array}$ & $\begin{array}{l}\text { Tea/coffee resulted in improved decision making, better critical } \\
\text { thinking and increase alertness }\end{array}$ \\
\hline & & Eating/Binging & Munching freshens, lessen effects of fatigue \\
\hline & & Smoking/Alcohol & Nicotine, stimulant \\
\hline & \multirow[t]{7}{*}{ Self- survival } & Micro naps & $\begin{array}{l}\text { Small sleep spells controls altered circadian rhythm, headaches due } \\
\text { to sleeplessness }\end{array}$ \\
\hline & & $\begin{array}{l}\text { Water } \\
\text { splashes/ablution }\end{array}$ & $\begin{array}{l}\text { water splashes maintain alertness/freshness, washes for praying to } \\
\text { relive anxiety and anger }\end{array}$ \\
\hline & & Praying & Spiritualism cope negative emotion, enhances positivity \\
\hline & & Micro breaks & Little breaks and small pauses, relaxation \\
\hline & & $\begin{array}{l}\text { Social media } \\
\text { usage }\end{array}$ & Using internet, face book keeps up-to-date and alert \\
\hline & & $\begin{array}{l}\text { Controlling digital } \\
\text { clock }\end{array}$ & Shrinkage of personal time, reducing sleep time and self-care \\
\hline & & Walking & Physical exercise maintain alertness and relieve mental exhaustion \\
\hline \multirow[t]{2}{*}{$\begin{array}{l}\text { Educational } \\
\text { Focus }\end{array}$} & \multirow[t]{2}{*}{$\begin{array}{l}\text { Prioritizing } \\
\text { studies }\end{array}$} & $\begin{array}{l}\text { Sufferings due to } \\
\text { studies }\end{array}$ & $\begin{array}{l}\text { Compromise on sleep time, personal time, family and friend time, } \\
\text { leisure time }\end{array}$ \\
\hline & & $\begin{array}{l}\text { Policy makers } \\
\text { concentrate }\end{array}$ & $\begin{array}{l}\text { Increase human resource (doctors), reduction in working hours, } \\
\text { MOCK exams }\end{array}$ \\
\hline \multirow[t]{2}{*}{$\begin{array}{l}\text { Support } \\
\text { System }\end{array}$} & $\begin{array}{l}\text { Consulting } \\
\text { seniors and } \\
\text { Peers }\end{array}$ & $\begin{array}{l}\text { Seeking help from } \\
\text { colleagues }\end{array}$ & Seeking seniors' help, taking little breaks, talking to staff around \\
\hline & $\begin{array}{l}\text { Support of } \\
\text { friends and } \\
\text { family }\end{array}$ & Family matters & $\begin{array}{l}\text { Hanging out with friends, obeying spouses quietly, Doubling duties } \\
\text { so can take day off, talking to friends and family, leisure time with } \\
\text { family }\end{array}$ \\
\hline
\end{tabular}

\section{Self-Regulation:}

The mental, physical and psychological status along with circadian rhythm was altered due to frequent, long working hours. Most of PGTs adopted the regulation of time to handle deleterious effects efficiently. So, they pre-planned and handled their concerns tactfully. Similarly, reflection on their own actions and self-control was another approach which produced a win-win situation. 


\section{Tailor Made Strategies:}

The adaptation of coping strategies by post-graduate trainees is found as per their requirement/ preference. Majority of PGTs practice frequent caffeine intake, eating/ binging, water splashes on face and ablution to avoid sleepiness especially, during night calls. Some seek refuge in praying. However, some believe in taking micro- breaks (breaks for 10-15 mins) and micro naps (sleep for 10-15 mins) to combat tiredness and sleepiness. Boys prefer smoking whereas, girls use social media to freshen up during long exhaustive duties. As these tactics maintains alertness, decision making and critical thinking of the PGTs on call. Using humour, joking with staff and laughing about the stressful incidences were also the coping strategies used by the residents.

\section{Educational Focus:}

The prolonged duty hours have grave consequences on the educational activities of these residents. They usually miss teaching rounds/morning classes and elective operation lists, due to late night calls. Furthermore, reported by many that they are physically present in class but mentally absent, therefore don't learn much. Nevertheless, PGTs counter these difficulties by reducing their sleep time (spending more time on studies), reducing time for self-care, spending less time with friend and family and shrinkage of leisure time.

\section{Support System:}

Support system encourages one to swim swiftly through the tiresome ocean of training. This support system comprises of family and friends, colleagues, peers and staff on duty. Similarly, seeking advice from seniors/ colleagues for patient safety was frequently stated by many. This support system has been identified as an important pillar of professional support. Where seniors and colleagues definitely helped their juniors, in times of need (exhaustion, poor alertness or sleepiness). Similarly, leisure time with family and hanging out with friend kept the boat rowing. Moreover, debriefing by the consultant after a challenging case, provided unconditional emotional \& educational support to the residents, as stated by participants.

\section{Discussion:}

This study has shown that some coping strategies were preferred by surgical PGTs while other were favoured more by nonsurgical discipline PGTs.

Minor difference among coping mechanism was probably due to difference in job demands and level of burnout of residents between the two specialties(17). The tailor-made strategies used by participants were caffeinated drinks, eating \& smoking, praying and social media usage to reduce their stress during extended duties. A similar study showed that positive philosophic out-look, spirituality, power naps, micro breaks, exercising and personal sacrifices are used as provocative measures by residents to overcome effects of long duties(12). Because these coping mechanisms make them alert both physically \& mentally helping them to take efficient decisions for their patients.

Moreover, PGTs self- regulate themselves through time management, self-control \& countering negative emotions which is well defined by problem/emotion based coping strategy. A similar study showed that both emotion focused and problem focused coping strategies used by the residents. These coping habits become the established habits of doctors to sacrifice their personal desires over the professional demands(7). This self-control will focus their critical thinking \& energies on their goal.

The novel coping strategies adopted by the PGTs working in various hospitals of Pakistan revealed by this study is that participants control negative emotions by self-counselling and social support system. They seek help from their families, friends, colleagues and other duty staff around. Similarly, a study showed that physician stress has been addressed by various means like, meditation, gratitude, exercise and healthy relations with friends \& family(14). 
Naturally, frequent extended duties result in to altered circadian rhythm. This altered rhythm was managed by Pakistani PGTs either by taking power naps or drinking plenty of caffeinated drinks. Similar tactics were opted in a former study, by anaesthesia residents, that is, caffeine intake, strategic naps, micro-breaks, controlled exposure to bright or blue enriched light during over night shifts and appropriate use of post - call recovery sleep(18). These tactics does not interrupt the patient care yet lessen the deleterious effects of long duty hours.

Furthermore, the fundamental goal of residency training is turning novices into experienced professionals, who would serve humanity as compassionate and competent healers. Therefore, didactic and clinical education is the right of residents and sufficient time and energy of his or her should be reserved for it. Therefore, educational setbacks are countered by doing personal compromises on sleep, family and leisure time. These positive strategies results in lower emotional exhaustion and depersonalization. As shown by a study that less emotional exhaustion and depersonalization is seen in the residents who seek compromise and productively resolve issues(10). Likewise, debriefing sessions by the consultant after a challenging case, provided unconditional emotional and educational support to the residents, as stated by participants. The literature also cited that debriefing sessions are emotional and social support for attendees(19).

Moreover, support from family and friends has been identified as an important pillar of professional support. Leisure time with family and hanging out with friend kept the boat rowing. Some other strategies used frequently by participants was talking to the co-worker and sharing humour at work place. Nevertheless, personal compromises (over the sleep, tiredness) seemed essential to handle tactfully the differences, especially with loved ones/spouses. Therefore, a collaborated program of cognitive behavioural therapy, mindfulness and coping skills should be adopted, and implemented for residents, as shown by literature(20).

Reliability \& authenticity of the study was ensured by maintaining the anonymity \& confidentiality of participants and a high response rate. Member checking and triangulation was done. Reflexivity was ensured.

Limitations of the study included, restricted number of FGDs due to Pandemic (travel restrictions). So, the multi-centric views of resident could not be gathered. Similarly, health safety limited the mobility of researcher to the hospitals.

Further studies are required to explore the evolving challenges of prolonged duties, on the post-graduate trainees in present scenario of digitalization.

\section{Conclusion:}

There was no significant difference found in the coping strategies, used by residents of surgical and non-surgical specialties. However, minor variation does exist as the surgical people are more prone to both mental and physical exhaustion, as compare to their parallels, due to nature of their job. Surgical trainees are more inclined towards eating and socialization with their dear ones. While non-surgical residents' uses spirituality as mainstay.

\section{Abbreviations:}

\begin{tabular}{|lll|}
\hline Sr. No. & Words & Abbreviation \\
\hline 1. & Post graduate trainee & PGT \\
\hline 2. & Focus group discussion & FGD \\
\hline 3. & Institutional review committee & IRC \\
\hline 4. & International conference of medical education & ICME \\
\hline
\end{tabular}

\section{Declarations:}


Study was conducted after institutional Review Committee (IRC) approval from RIPHAH International University, Islamabad (Appl\#Riphah/IRC/20/123). Informed consent to participate in the study was obtained from all participants.

\section{Consent for publication:}

Not applicable.

\section{Availability of data and material:}

The datasets supporting the conclusions of this manuscript are included within the article (and its additional files).

\section{Competing interests:}

The authors declare that they have no competing interests.

\section{Funding:}

Nothing to declare.

\section{Authors' contribution:}

SM[1] (corresponding author) Contributed for conception \& design of this study, prepared the figures.

MS[2] has revised the work.

IA[3] contributed for acquisition \& interpretation of data.

AR[4] has drafted the study.

All authors have approved the manuscript before submission.

\section{Acknowledgements:}

Not applicable.

\section{References:}

1. Dembe AE. Ethical issues relating to the health effects of long working hours. J Bus Ethics. 2009;84(2):195-208.

2. Pereira-Lima K, Loureiro SR. Burnout, anxiety, depression, and social skills in medical residents. Psychol Health Med. 2015;20(3):353-62.

3. Gander PH, Merry A, Millar MM, Weller J. Hours of work and fatigue-related error: a survey of New Zealand anaesthetists. Anaesth Intensive Care. 2000;28(2):178-83.

4. Flinn F, Armstrong C. Junior doctors' extended work hours and the effects on their performance: the Irish case. Int J Qual Heal care. 2011;23(2):210-7.

5. Lemaire JB, Wallace JE. Not all coping strategies are created equal: a mixed methods study exploring physicians' self reported coping strategies. BMC Health Serv Res. 2010;10(1):208.

6. Folkman S, Lazarus RS, Gruen RJ, DeLongis A. Appraisal, coping, health status, and psychological symptoms. J Pers Soc Psychol. 1986;50(3):571.

7. Ratanawongsa N, Wright SM, Carrese JA. Well-being in residency: a time for temporary imbalance? Med Educ. 2007;41(3):273-80.

8. Isikhan V, Comez T, Danis MZ. Job stress and coping strategies in health care professionals working with cancer patients. Eur J Oncol Nurs. 2004;8(3):234-44. 
9. Le Blanc PM, Schaufeli WB. Burnout among oncology care providers: Radiation assistants, physicians and nurses. Occup Stress Serv Prof. 2003;143-68.

10. Doolittle BR, Windish DM. Correlation of burnout syndrome with specific coping strategies, behaviors, and spiritual attitudes among interns at Yale University, New Haven, USA. J Educ Eval Health Prof. 2015;12.

11. Wallace J, Lemaire J. Physician coping styles and emotional exhaustion. Relations Ind Relations. 2013;68(2):187-209.

12. Stoller EP, Papp KK, Aikens JE, Erokwu B, Strohl KP. Strategies resident-physicians use to manage sleep loss and fatigue. Med Educ Online. 2005;10(1):4376.

13. Wild K, Scholz M, Ropohl A, Bräuer L, Paulsen F, Burger PHM. Strategies against burnout and anxiety in medical education-implementation and evaluation of a new course on relaxation techniques (Relacs) for medical students. PLoS One. 2014;9(12).

14. Satterfield JM, Becerra C. Developmental challenges, stressors and coping strategies in medical residents: a qualitative analysis of support groups. Med Educ. 2010;44(9):908-16.

15. Creswell JW, Klassen AC, Plano Clark VL, Smith KC. Best practices for mixed methods research in the health sciences. Bethesda Natl Institutes Heal. 2011;2013:541-5.

16. Palinkas LA, Horwitz SM, Green CA, Wisdom JP, Duan N, Hoagwood K. Purposeful sampling for qualitative data collection and analysis in mixed method implementation research. Adm policy Ment Heal Ment Heal Serv Res. 2015;42(5):533-44.

17. Pejušković $B$, Lečić-Toševski D, Priebe $S$, Tošković $O$. Burnout syndrome among physicians-the role of personality dimensions and coping strategies. Psychiatr Danub. 2011;23(4.):389-95.

18. Wong LR, Flynn-Evans E, Ruskin KJ. Fatigue risk management: the impact of anesthesiology residents' work schedules on job performance and a review of potential countermeasures. Anesth Analg. 2018;126(4):1340-8.

19. Gunasingam N, Burns K, Edwards J, Dinh M, Walton M. Reducing stress and burnout in junior doctors: the impact of debriefing sessions. Postgrad Med J. 2015;91(1074):182-7.

20. Chaukos D, Chad-Friedman E, Mehta DH, Byerly L, Celik A, McCoy TH, et al. Risk and resilience factors associated with resident burnout. Acad Psychiatry. 2017;41(2):189-94.

\section{Figures}

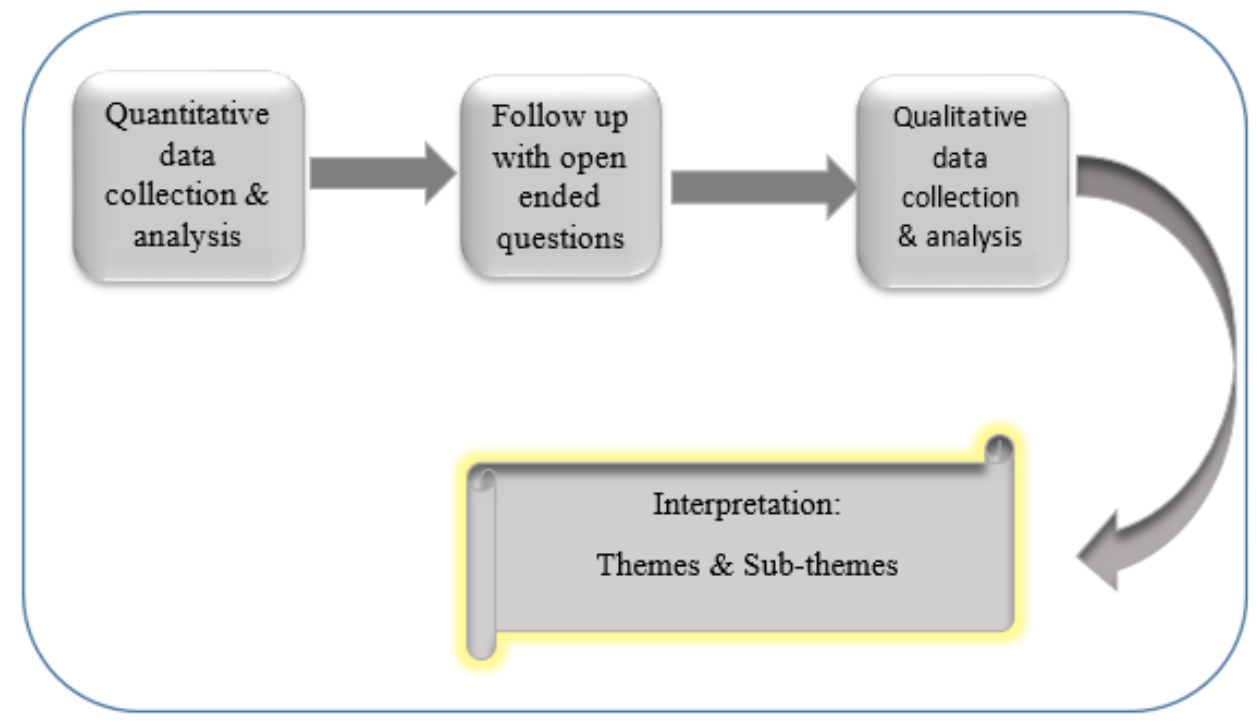

\section{Figure 1}

Explanatory Sequential Design(Mixed Method Study) 


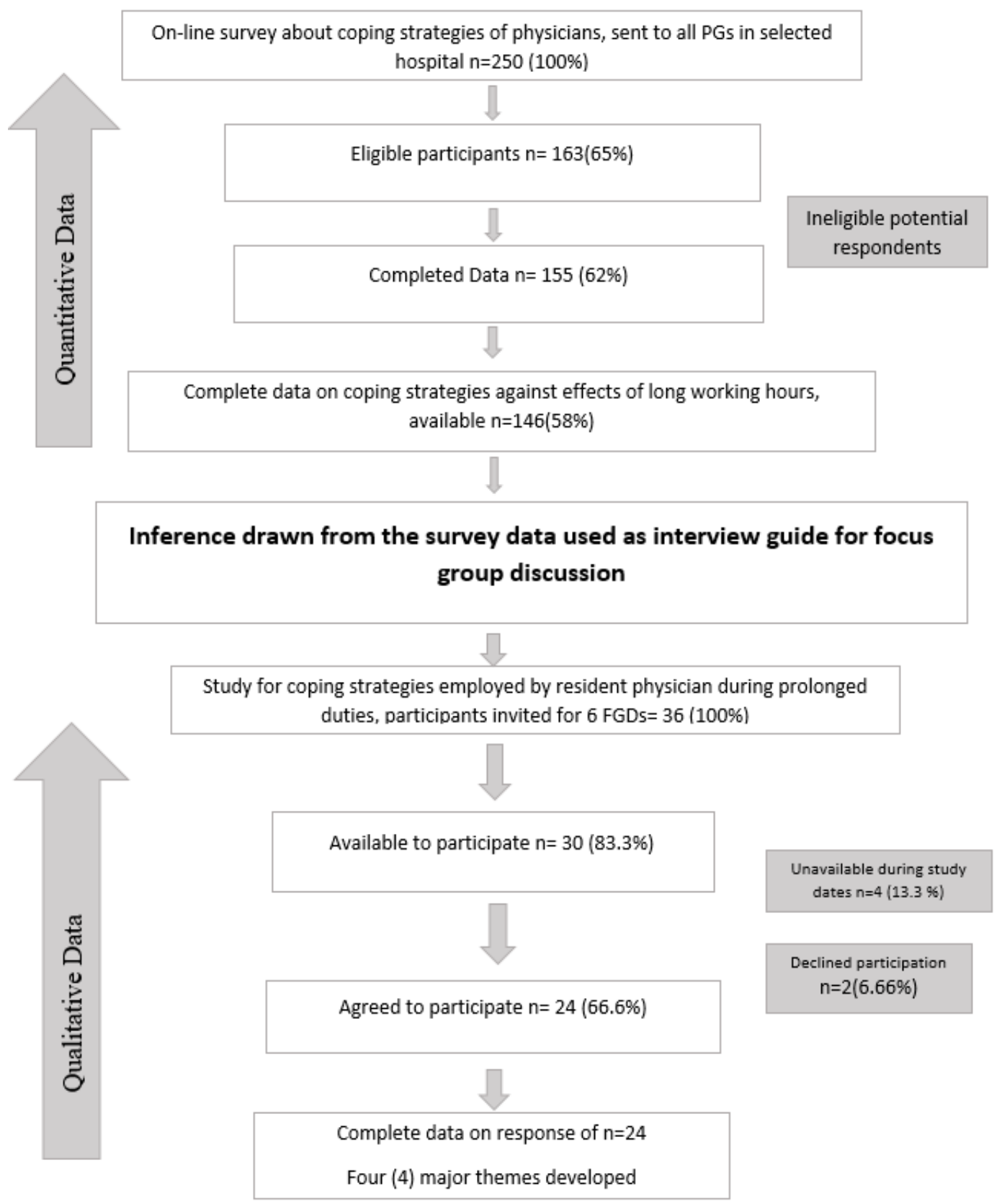

Figure 2

Mixed Method study Design Flow chart 